\title{
THE DEVELOPMENT OF E-LEARNING AMONG PRIVATE UNIVERSITIES IN SARAWAK, MALAYSIA
}

\author{
Andrew Sija ${ }^{i}$ \\ University College of Technology Sarawak, \\ School of Business Management, \\ Malaysia
}

\begin{abstract}
:
E-learning is playing very important role in the present educational scenario. It has potential to change the whole education system and due to this reason, it has become one of the most preferred subjects for the researchers and scholars working on the various aspects of e-learning. This study is looking into various research works on e-learning for IPTS (Private Institutions of Higher Learning) in Sarawak. The principle objectives of this research includes to examine the suitable research model describing on the methods that shows the motivation in e-learning, (ii) to identify the suitable type of learning in higher education and (iii) to investigate the problems and challenges of implementing e-learning in Private Institute of Higher Learning Sarawak. This study therefore examined the prime factors of two selected IPTS in Sarawak (Saujana Academy of Travel and Tour (SATT) and IBS College (formerly known as Institute BREM Sarawak) in implementing an Elearning and the relations between each influencing factors of acceptance in E-Learning in the University/Colleges by adopting the two basic types of learning which were Computer Based Learning and Internet Based Learning as proposed by Algahtani, 2011. The resulting analysis and interpretation provided a description of the performance of ELearning influenced by the variables which were the engagement of E-Learning, facilities and computer literacy. The qualitative method in this study derived from a constructive perspective involving in-depth face to face interview with the respondents. The outcome of this study depicted that the influence of internet connectivity and computer-based knowledge equipped the E-Learning implementation and discovered of the advantages and disadvantages of E-Learning in education industry. Based on the findings, three primary variables identified with supporting factors emerged as the critical components categories in this study and these categories represent a conceptual framework for solving E-Learning issues.
\end{abstract}

Keywords: e-learning, IPTS (Institute of Higher Learning), engagement of e-learning, facilities, computer literacy, performance of e-learning

i Correspondence: email dr.rews@yahoo.com 


\section{Introduction}

The E-learning or electronic learning which was firstly initiated to have been coined by Cross in 1998 (Dublin and Cross, 2002). It's a learning is where the learning process and acquiring of knowledge with the support of technology or computer network. Specifically, several notable definitions of e-learning describe the utilization of ICT within educational and training programs. In Scientific definition by NCSA e-learning group (Adeoye \& Wentling, 2007), the definition were:

"The acquisition and use of knowledge distributed and facilitated primarily by electronic means. This form of learning currently depends on networks and computers but will likely evolved into systems consisting of a variety of channels (e.g. wireless, satellite), and technologies (e.g. cellular phones) as they are developed and adopted. E-learning can take the form of courses as well as modules and smaller learning objects. E-learning may incorporate synchronous or asynchronous access and may be distributed geographically with varied limits of time."

Alternatively, American Society for Training and Development (ASTD) has defined E-learning in 1998 as a broad set of applications and processes which include web-based learning, computer-based learning, virtual classrooms, and digital collaboration. Much of this is delivered via internet and intranet (Bernthal, 2004). However, according to the World Bank (Badiee, 2009), E-learning refers to the use of computer based electronic technologies of internet, email, websites and CD-ROMS, and their applications, to deliver, facilitate and enhance both formal and informal learning and knowledge sharing.

\subsection{A Brief of E-Learning in Sarawak}

Sarawak is one of the country's education hubs with both public and private institutions of higher learning housed. The rapid growth of web-based technologies and the high internet consumption in the town of Sarawak has made the learning in the public and private institutions becoming more rigorous and viable in the recent years. According to Khalid et al. (2006), many universities and colleges have set up portals to offer an elearning environment either as teaching aids to support conventional teaching approach or as a teaching medium for long distance or off campus programs. In Sarawak, there are currently housed with 4 public universities, three private universities and over 20 colleges (www.jpt.moe.my). With an increase in the demand of higher education in Sarawak, many institutions here have planned for e-learning and these institutions have responded actively, however not all of these institutions have the capability and readiness for adopting an e-learning in their current learning system. Referring to survey conducted in 2004 by Asirvatham, Kaur \& Abas, showed that generally (i) Malaysia is moderately ready for e-learning, (ii) Malaysia is not environmental ready, (iii) Malaysia is technically ready, (iv) Enablers are mostly ready, (v) learners are more ready for elearning compared to the perception of their lecturers and (vi) Malaysia is not seen as 
financially ready by providers and policy makers. As for private institutions of higher learning in Sarawak, this considered the right time to explore adopt this new learning system. Online delivery enables the flexibility in teaching while the learners can learn anywhere, anytime. Thought, there were a number of studies that point out the challenges and issues in implementing e-learning, for sample McKenzie (1998) described that the e-learning would fail if utilizing particular information technologies for their own sake, without sufficient regard for appropriate learning design. Towards at the end of this study, the researcher believed that the instructors and the learners in Sarawak IPTS would have to grapple with unfamiliar terms such as Asynchronous, Synchronous, and blended with Asynchronous and Synchronous online delivery while navigating learning Management System (LMS) and other systems. These would make learning via Elearning system becoming more interesting.

\subsection{Objectives of the Study}

The specific objective of this study is to examine the suitable research model describing on the performance, methods and types of E-Learning which could provide valuable information and learning experience to the educational learning.

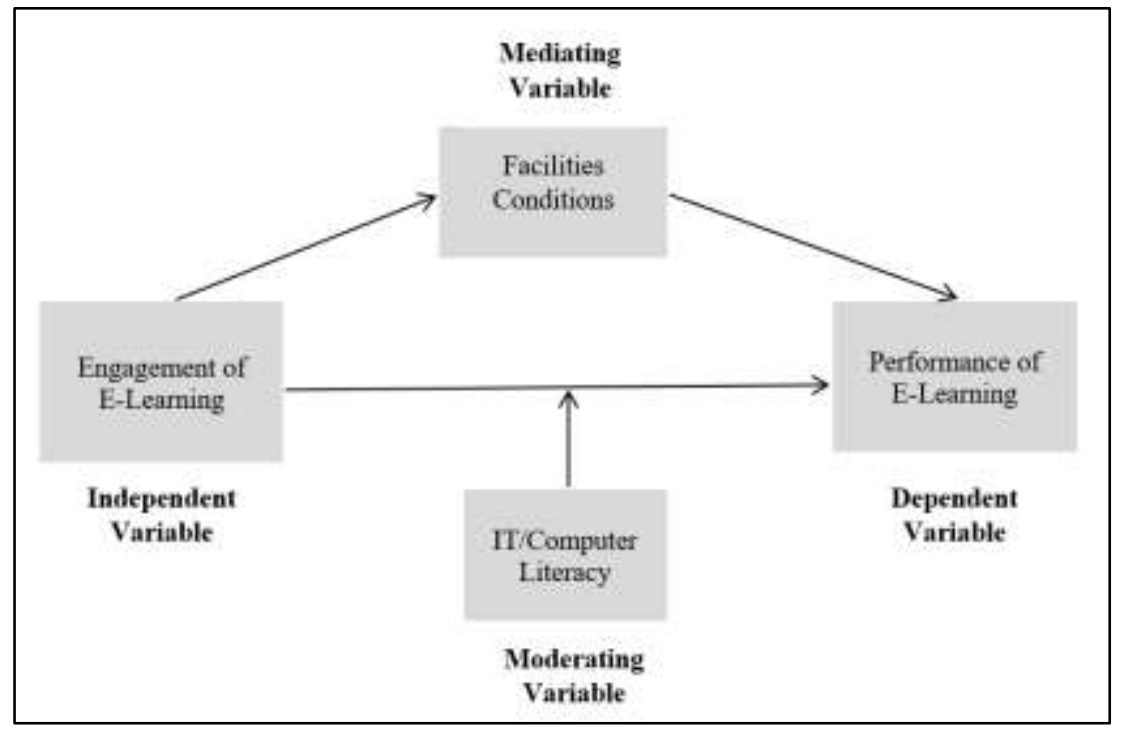

Figure 1: A Conceptual Framework of E-Learning

\section{Literature Review}

The rigorous advancement in information technology in business, education and training has made the industries to stay competitive and gain innovative advantages. It allowed productive improvement in terms of delivery of information, provision of analytical tools, the elimination of distance barriers and reduce repetitive tasks (Kim \& Kim 2006; Leidner \& Jarvenpaa, 1993). Indeed, there are a number of surveys that have been carried out to identify the critical success factors for E-learning. Cited from Webster and Hackley in 1997, they emphasized the factor of effectiveness, and measured by learners'] involvement and participation, cognitive engagement, technology self -efficacy and 
perceived usefulness of technology used for measuring the effectiveness of adopting Elearning. Beside, Sanders \& Nagelhout (1995) added the reliability and quality as a medium of richness key factors for successfulness in E-learning system. A survey by Lim (2001) demonstrated that computer self-efficacy was an important element in adult learner's satisfaction and performance for future web-based courses. While, self-efficacy was influenced by computer experiences and knowledge (Tarkzadeh \& Koufteros, 1994) which include years of computer usage and internet experiences contribute to the positive relationship with adult learner's satisfaction in learning. Laudon and Laudon (1998) critically identified the success factors for implementing E-learning and they have concluded that organization's support, user participation, degree of complexity and risk of new technologies were vital. For this study, after reviewing the past connected research, the researcher has made a conclusion on the integrated variables below:

\subsection{Engagement of E-Learning}

In 2018, a survey has been conducted, of the 200 organizations took part, it was found that there was a total of 28 different learning management systems being used. And 71\% respondents found that engagement was the most challenging part in E-Learning. Learner's engagement was characterized by the willingness to interact consistently with the course provided in order to achieve a learning goal, and this willingness were absolutely relating to curiosity, interest, perceived value and reward. Pongpech (2013) revealed that learners' interaction with online learning activities have a significance impact on learner's exam scores. Several studies have shown the course outcomes are positively correlated with student engagement. For sample, Atherton at al showed that the students who access web-based system study materials daily and undergo regular assessment achieve high exam scores. However, most of the previous work on engagement has focused on traditional education in Universities / colleges /schools but has neglected student engagement in web-based systems.

\subsection{Facilities Conditions}

The survey in 2018 revealed that a part from the engagement of the learners become the most challenge in E-learning, the lack of resources which includes the facility used was one of the important factor, about $27 \%$ respondents believed that without good facilities, performance of E-learning could be jeopardized. Lack of information regarding utilization of existing ICT facilities appeared to be the problem that interrupt the process of student interacting with e learning facilities. Technology is vital in implementing and adopting e-learning because of its required both sides, the learners and the institutions. Any organization that wish to implement E-learning, they need to make sure they have the appropriate capacity in terms of the system which includes the hardware, software and connectivity. Many e-learning programs conducted in the institute of higher learning are dead on arrival due to an inability to install the right software, establish connectivity, or maintain security (Horton, 2011). 


\subsection{Performance of E-Learning}

Generally, the awareness about what is e-learning in Sarawak and what are its benefits were still much to improve. The lack of awareness might forbid the prospective learners or institutions from adopting and using e-learning. Thus, the performance of e-learning in Sarawak would be very much depend on the planning and awareness (Bhattacherjee, 2002; Navarra and Cornford, 2003; Reffat, 2003). There were some challenges concerned with IT infrastructure in Sarawak. The respective government or the organization should have an appropriate strategy in developing an IT infrastructure through proper planning, developing proper network and communication infrastructure and upgrading the internet speed and bandwidth network access capacity particularly in the rural area. Since e-learning is expected to provide access to most Sarawak students, academic, consultant and management, thus the IT standards and resources must be well established and integrated to avoid any difficulties in conducting E-learning.

\subsection{Information Technology \& Computer Literacy}

Assuming the absence of technical support would be a significant factor for stopping the e-learning project because of the learners are not familiar with e-learning technologies and procedures. Mahmood et al.(2001) stated that technical support as people assisting the users of computer hardware and software products, which can include hotlines, online support service, machine readable support knowledge bases, faxes, automated telephone voice response systems, remote control software and others. The literacy of the users in all of these become essential and important in the acceptance of technology for teaching (Hofmann, 2002).

\section{Material and Methods}

\subsection{Population and Sample}

For this study, a qualitative variables from the interview were analyzed to obtain the primary data. The sampling for this study was based on the respondents at SATT College Kuching and IBS College Miri, Sarawak. Structured interview was conducted with all respondents with all the questions fully well prepared. According to Lee and Fielding (1991), the interview is one of the most important sources in qualitative data collection. Interviews were facilitated by an interview guide that was developed during the date collection process. To be more effective, the pilot interviews were actually been conducted with few E-learning researchers and practitioners from a different colleges / institutions. Based on the pilot interviews results, the questions and interview guide were have to revised and if necessary to modified. This is to prevent any unforeseen or misdirection of the topics during the interview session. The questions on the interview guide were firstly on general E-learning information, current E-learning implementation in higher educational institutions in Sarawak and moved to the problems and challenges encountered during the implementation and adoption of E-learning. The interview was conducted in a professional manner which involved the relevant staff (academic and nonacademic) who had used and adopt E-learning. Prior conducting the interview, the 
researcher has already identified the targeted number of respondents to be interviewed and this has to be accurate and with the ones who can give the best answers to the questions being asked. The study was limited to higher educational institutions in Sarawak, where twenty (20) respondents have been chosen, and they were all contacted first prior to the visit and being interviewed. All of them were chosen based on convenience and practical reasons since the researcher knowing their opinions could help for improvement in these services.

\section{Results and Discussion}

Table 1 depict the demographic profile of 20 respondents from 2 institutions, namely IBS College and SATT College. The used of E-learning in their studies is relatively common to all of the IPTS students nowadays including students of IBS and SATT. Based on table 1 , there were only three considered main variables in the demographic profile section. The researcher considered the equal distribution for both genders in order to generate unbiased data from the respondents. Based on the table, $40 \%$ were Chinese respondents, followed by Malay, 35\% and the remaining 15\% and 10\% were for Iban and other ethnic respectively.

Table 1: Interviewees' Characteristics

\begin{tabular}{llcccc}
\hline Variables & Particulars & Frequency & IBS & SATT & Percentage \\
\hline Gender & Male & 10 & 5 & 5 & $50 \%$ \\
\multirow{3}{*}{ Race } & Female & 10 & 5 & 5 & $50 \%$ \\
& Malay & 7 & 3 & 4 & $35 \%$ \\
& Chinese & 8 & 4 & 4 & $40 \%$ \\
\multirow{4}{*}{ Age } & Iban & 3 & 1 & 2 & $15 \%$ \\
& Other & 2 & 2 & - & $10 \%$ \\
& $20-30$ & 12 & 5 & 7 & $60 \%$ \\
& $31-40$ & 4 & 3 & 1 & $20 \%$ \\
\hline
\end{tabular}

Table 2: Closed Ended Structure Question Summary

\begin{tabular}{lccc}
\hline Statement & Yes & No & Total Percentage (\%) \\
\hline Engagement of E-Learning & 70 & 30 & 100 \\
Facilities Conditions & 80 & 20 & 100 \\
Performance of E-Learning & 50 & 50 & 100 \\
IT / Computer Literacy & 90 & 10 & 100 \\
\hline
\end{tabular}

Table 2 provides information about the summary of closed ended structure questions being asked to the respondents. There were four statements attached with the first statement asking the respondent when would be the exact time the college / institution engaged in E-learning, followed by the second statement on the availability of the facilities provided for conducting E-learning. The third statement was on how the respondents perceived the performance of E-learning currently and the final statement was related on the importance having literacy in IT and computer support the adoption 
of E-learning. It was observed that all of the 20 respondents that being interviewed, $90 \%$ of the respondents supported strongly the essential role of IT and literacy in computer for adopting E-learning. They agreed that students / users must be an IT savvy. On the engagement of E-learning and facilities, about $70 \%$ and $80 \%$ of the respondents realized and aware of the college / institution they were in moving into E-learning and they emphasized on the usefulness of having complete facilities. However, when asked on the performance of E-learning adopted, half of the respondents believed the E-learning system implemented currently is functioning towards institutional goals and another half of the respondents perceived that the E-learning was just in the early stage and much efforts needed for building up the system.

\subsection{Clusters Developed in this Qualitative Study}

Table 3: Qualitative study cluster

\begin{tabular}{ll}
\hline Cluster & Characteristics \\
\hline Engagement of E-learning (EL) & $\begin{array}{l}\text { Relate to management awareness, support and commitment } \\
\text { provided }\end{array}$ \\
Facilities Conditions (FC) & $\begin{array}{l}\text { Availability of infrastructure, technical support and training } \\
\text { provided } \\
\text { The methods for improving performance and relative } \\
\text { advantages }\end{array}$ \\
Performance of E-learning (PE) & Awareness, IT Savvy and knowledge \\
\hline
\end{tabular}

\subsection{Engagement of E-learning}

Interview Questions:

EL1: How long is the implementation of full E-learning at your college/institution?

EL2: Do you think this college/institution is fully aware on the benefits of using Elearning system? Explain

EL3: In general, do you believe that your management would give support on the use of this system now and in future?

The respondents were asked on the implementation of E-learning currently adopted and level of awareness the management had with what kind of supports given. Most of the interviewees agreed in respect of the importance of the awareness and support by the management to implement E-learning. Below was the distinctive difference between the thoughts of respondents from the two colleges/institutions. For example, an officer in one of the colleges where an E-learning have just adopted recently, said:

"I'm not sure about the awareness of our organization on when they really implement this E-learning, but as far as I'm concerned, we are just started and the strategy and awareness on the advantages of E-learning adoption is still quiet new." (Male respondent: Interviewee 5) 
However, an officer from the other college/Institution where an E-learning system is implemented said:

"Definitely, our management is fully aware of the advantages of adopting E-learning system for our students and staff. Our IT department was tasked to review any possible problems arising and they do provide the support and assistance." (Male respondent: Interviewee 12)

When the respondents were asked on the role their management and process required in adopting and implementing E-learning, many of them unsure was quite confused and they didn't or can recognize the process. They believed that at this stage, proper planning, designing and updating plus reviewing need to be properly outlined. One of the interviewees who was a manager where E-learning system is implemented said:

"As our IT people were already tasked for this, they are responsible to develop an effective E-learning system, and we are quite sure that they (IT) have the plan for acquiring the software or technologies concerned." (Male respondent: Interviewee 15)

An Academic said:

"I knew about E-learning in few years back, I want to see my management fully moving towards on this, they must act quickly for new generation way of learning. Purchase of some necessary hardware or equipment is indeed." (Male respondent: Interviewee 8)

"I'm aware of the benefits of using and adopting E-learning in our lecture, it's so much flexible for me when deliver a notes and conducting classes. It's gave me a systematic way in planning our work, and I believed it's the time for the management to give support." (Female respondent: Interviewee 2)

Based on the above selected responses for the finding on the engagement of Elearning, it shows that most of the respondents being interviewed were aware on the development of E-learning surrounding them. With the advancement in the technology and the new way of doing work with more rigorous and effective, respondents agreed on the support from the management is vital for them to fully commit on the implementation of E-learning in their organization.

\subsection{Facility Conditions}

Interview questions:

FC1: Does the college/institution have the resources and practical knowledge to adopt the E-learning system?

FC2: Does the training program and support were provided to the users (students and staff)? Explain. 
In this context of study, this cluster represent by the perception of individual believes that the organizational and resources which includes the technical infrastructure exist to support the E-learning adopted. Chau and $\mathrm{Hu}$ (2002) found that this cluster have a significant predictor of the actual use of technology for E-learning. For this interview, the interviewee was asked on the necessary resources, knowledge and training support for E-learning provided by the management. Since both of the colleges/institutions yet to have full E-learning system, some respondents could not give definite answers. Many respondents said their organizations have good infrastructure and some technology to adopt the E-learning but in term of the system, it is still new. Most of them perceived that facility condition is very important for the implementation and embark into E-learning. Refer to the sample of interviewee comments below:

"Physical infrastructure undeniable necessary for E-learning implementation. In our organization, I observed we have quiet up to date infrastructure and this can be utilized to implement the E-learning system, however, we still have to look and identified the most effective type of E-learning system to be adopted. We were exploring into it." (Female respondent: Interviewee 17)

"I'm not that well verse in IT, but I think the practical knowledge indeed important to have E-learning system. Without it, may cause problem such as delaying in the process, but I do believe that with proper training and support provided may ease these problems." (Female respondent: Interviewee 4)

An academic teaching computer science:

"I do not think it will be a problem to use E-learning system applied in our teaching plan. Reason being, we already have a knowledge in IT and computer, considered qualified. It is just a matter of learning the additional system. But those who do not have the knowledge, the training program could support them." (Male respondent: Interviewee 13)

"We have this E-learning system, which was introduced not long ago, unfortunately not fully using it. To make it more integrated for one system to another, I personally believed that proper structure training programs should be given." (Female respondent: Interviewee 16)

\subsection{Performance of E-Learning}

Interview questions:

PE1: Do you believe that using E-learning system could enhance the quality and improve efficiency in learning?

PE2: In what way the E-learning system could benefit the users and institution of higher learning in Sarawak?

In this context of study, this cluster represent by the perception of individual believes that the use of E-learning system in the organization could bring many benefits 
such as improvement in quality and efficiency. It is also able to facilitate proper communication and reducing costs (Al-Shafi et al., 2009). The findings indicated that most of the respondents strongly believed that using E-learning would improve their work performance and completing them ahead of the schedule. To verify this, the interviewee in this survey were asked on the possible potential benefit of using E-learning in their organization. Hence, there were two sides of the feedback gotten, the first one was from where E-learning already implemented and the other one was where the Elearning was just adopted. Overall, both sides of the responses alluded complimented the use of new technology was prelude to the organization goal and strategy. Refer to the sample of interviewee comments below:

"The advancement in the technology and digitalization can spearhead improvement in education process. It's undeniable and we have to adapt into it. We could have all the resources, but entirely depends on the decision made by the top management." (Male respondent: Interviewee 5)

By comparing the traditional system and E-learning system, when asked again in what way the E-learning could benefit the users, most of the interviewees strongly agreed that E-learning system could save their time particularly during teaching, conducting courses, sharing and posting notes and documents, thus making the learning process more interesting. Refers to one of the academic staff who is currently using E-learning in her work:

"With E-learning, I could easily make an announcement and uploading my notes and documents prior the class commencing. But before E-learning was implemented, I had to manually distribute and printing the notes, it caused troublesome." (Female respondent: Interviewee 11)

"Using E-leaning system make me more productive as I can easily monitored and communicate with students. Any enquiries from the students were well addressed." (Male respondent: Interviewee 20 )

"I think E-learning would be very useful in easing the burden of lecturer when come to grading and checking students' marks, particularly when involve huge number of students." (Female respondent: Interviewee 10)

\subsection{Information Technology / Computer Awareness}

Interview questions:

ICA 1: Do you think the users of the E-learning system must be an IT savoy and how could the management encounter this?

In this context of study, this cluster represent by the perception of individual believes on the importance of having awareness on IT and computer. Its highlights general thoughts of the interviewees on the readiness and exposure on IT/computer 
essentially helping the building of E-learning system. The findings indicated all of the respondents strongly supported the awareness in IT / Computer prior adopting Elearning system. As most of the process involved in connecting the E-learning system in the organization may require someone to be an IT savvy. To verify this, the interviewee in this survey were asked perceived awareness on IT/computer knowledge when prior adopting E-learning and the way management could navigate this issue if found that the users were not an IT savvy. Refer to the sample of interviewee comments below:

"I personally believe essential knowledge in IT and computer is a must for everyone in the organization. It could help the management when new system is adopted." (Male respondent: Interviewee 1)

"My IT / computer skills were average, but I do not see it as a barriers for using E-learning. Special couching, short training, briefing and attachment could overcome this." (Male respondent: Interviewee 3)

Hence, the overall findings of this study discovered that all the analyzed data tend to be corroborate to the recommendation on solving E-learning issues in Private Institution of Higher Learning (IPTS) in Sarawak. It affirmed that in this conceptual model, the performance of E-learning in Private Institution of Higher Learning, Sarawak was influenced by independent variable i.e. Engagement of E-learning and mediated by facilities conditions while moderated IT / Computer Literacy.

\subsection{Discussion}

The main target is to quantify the relationship between performance of E-learning and engagement of E-learning mediated by facilities conditions and moderated by awareness of IT and computer in adopting and implementing the E-learning system in Private Institution of Higher Learning in Sarawak. Notably, the study revealed that the lack of management support and awareness was the main reason why E-learning is slow implemented in Sarawak. The issues encountered such as management support and commitment were totally related to management awareness engagement compliment the influence in E-learning. Moreover, decision making and top management in Private Institute of Higher learning (IPTS) Sarawak should understand and forward looking into the benefits and competitive advantage of adopting E-learning system in their organization. This study opined that in order to fully implement the E-learning system, the support and awareness from the users such as government, decision makers and employees are very much needed. On facilities conditions, the survey findings showed that the relationship between facilities conditions mediating the adoption of E-learning in the Private Institutions of Higher Learning (IPTS) was significant vital as most of the respondents signifies the importance of having complete infrastructure, technical support and guided training program offered. Moreover, most of the Private Institute of Higher Learning in Sarawak are relatively small and new to the E-learning system. Thus, new and up to date hardware and software could facilitate the development of E-learning 
rigorously and successfully implemented. Whilst, the performance of E-learning at this point of time have to be reviewed, with thoroughly analyzed. The exploratory interviews conducted in this study showed that the academics and non-academic professionals in the sample believed that there were huge benefits and advantages gained in both organizations and it's confirmed that by using E-learning it would steadily improve their job performance and furthermore the tasks can be completed faster. This study further confirmed that the positive and strong influence of performance of E-learning can improve the quality of learning and quantity of services not forgotten the value of money that could be saved. Aside from that, the knowledge with constant awareness of IT and computer were essential to all of the users in the institutions of higher learning, with focusing on for more integrated and vulnerable system to be used on E-learning, thus improve the accessibility of installing, adopting and maintaining the system.

\section{Recommendations and Implication}

Although many studies have been carried up and conducted on the adoption of Elearning abroad, the author of this study was convinced to argues that just few studies on the adoption of E-learning were conducted in many developing country, however in Malaysia, particularly in Sarawak, the study on the E-learning adoption considered new, thus further exploratory is needed. Since there were no comprehensive studies about the adoption of learning in Sarawak, with lack of usefulness empirical studies and research has resulted little understanding to the users, thus making this study indeed contributed to the literature and knowledge in this field of E-learning. Notably, there were three (3) incredible considerations found on the E-learning trend in this study. For instance, the researcher has discovered the acceptance of E-learning (AEL) among users. Learners acceptance demonstrate his/her willingness to use and adopt the system, although Elearning is increasingly used in the Malaysia tertiary distance learning institutions, but how well was this system fulfill the need of distance learners as a learning medium has not well studied. For sample, Hong, Lai and Holton (2003) investigate a web based course at University Malaysia Sarawak and found that more than half of the participants had high level of acceptance and they concluded that learners who had high level of acceptance reported the web based course was convenience and flexible. Nonetheless, some learners do faced difficulties with that web-based learning environment, particularly those who were having poor internet connectivity. Secondly, the availability of present technology status used and the future potential outcome on E-learning in Sarawak. This type of trend could be further analyzed due to some factors such as the efficiency internet connectivity in rural Sarawak was limited, hence making the adoption of E-learning become more challenging. The technology and system support were the factors contributing to the acceptance of E-learning as mentioned by Florunso et al, 2006. It is important to look into the reliability and quality of the system as it plays an important role as well as up to date E-learning system. The last consideration was on the issues related to high population, geographical decent varieties, imperative of budget for the 
organizations and the adaptability issue. All of these would need a conclusive support from the Government and the management.

On the implication of this study, the researcher has highly recommended that the result of this study could have benefited three parties namely the Ministry of Higher Education (MOHE), Private Institute of Higher Learning (IPTS) and the Instructors. There is a need for these three parties to cooperate and collaborate in improving the adoption of E-learning in Sarawak. This could be very crucial particularly issue related to the design, tools, learning program and entire implementation. Some recommendation for MOHE is to create a national e-Learning training policy to help improve the direction to coordinate the training programs in all IPTS in Sarawak. On the Private Institute of Higher Learning (IPTS), the researcher believed the management would focus on the management of E-Learning Training and E-Content Development Training. The Elearning Training Management would strengthen the efficiency and education quality of that IPTS in adopting the system and guided structure programs could be used or introduced to its staff. The guided structured program would consider the development of latest technology which includes web 2.0, 3-0, 4.0, technologies related to mobile and LMS. Hence, in the context of this study, the finding showed more could be done to improve the learners' acceptance of E-learning in Sarawak. Distance learning institutions in Malaysia should assist lending their expertise and support to the other institutions who have yet adopting the E-learning system. This is to maximize the use of E-learning for learning purposes in Sarawak. The researcher proposed model in this study could be used as a frame by Private Institution of Higher Learning in Sarawak particularly that opt to implement and adopt E-learning systems. Furthermore, it could be used as a tool in decision making in supporting the organizations efforts in implementing the effective learning system.

\title{
Conflict of Interest
}

The author can assure, confidently express that no conflicts of interest possibly linked with this research, and there has been no significant financial aid received for this study, authorship and publication that could have influenced the study's outcome. The author affirms that this research is original and has not been published in the past or elsewhere.

\begin{abstract}
About the Author
Andrew Sija is lecturer in the Faculty of Business Management at University College of Technology Sarawak, Malaysia. He is a Certified Trainer in Business Accounting, PSMB and an Instructor for Accounting for Hospitality Industry, AHLEI. His research area is on accounting, banking related, business and management.
\end{abstract}

\section{References}

Adeoye, B. \& Wentling, R. M. (2007). The relationship between national culture and the usability of an e-learning system. International Journal on E-learning, 6, 119-146. 
Al-Rahmi, W. M., Othman, M. S. \& Yusuf, L. M. (2015). The Effectiveness of Using ELearning in Malaysian Higher Education: A Case Study Universiti Teknologi Malaysia. Mediterranean Journal of Social Sciences, Vol 6 No 4 S2.

Al-shafi, S., Weerakkody, v. \& Janssen, M. (2009). Investigating the adoption of eGovernment services in Qatar using the UTAUT model. AMCIS 2009 Proceedings, 260.

Ashraf M. H. Abdel Gawad \& Khalefah A.K. Al-Masaud. Impediments of activating elearning in higher education institutions in Saudi Arabia [PDF file]. Retrieved from https://mafiadoc.com/impediments-of-activating-e-learning-in-highereducation-institutions- 59a46c771723dd0b40ac8bd5.html.

Azhari, F. A. \& Long, C. M. (2015). Review of e-learning Practise at the Tertiary Education Level in Malaysia.

Azizi, N. A. (2017, September 26). Retrieved from https://www.nst.com.my/news/nation/2017/09/284259/malaysia-forefront-elearning.

Badiee, S. (2009). Statistics for small states : a supplement to the World Development Indicators (WDI). Washington DC.

Becta. (2003). Primary Schools - ICT and Standards. [PDF file]. Retrieved from https://dera.ioe.ac.uk/1700/1/becta 2002 ictstandards analysisreport.

Bernthal, P. R. (2004). ASTD 2004 competency study: Mapping the future: New workplace learning and performance competencies, American Society for Training and Development.

Bhattacherjee, A. (2002). Individual trust in online firms: Scale development and initial test. Journal of Management Information Systems, 19, 211-242.

Bradford, P., Porciello, M., Balkon, N., \& Backus, D. (2007). The Blackboard Learning System: The Be All and End All in Educational Instruction? Journal of Educational Technology Systems, 35(3), 301-314. doi:10.2190/x137-x731-5261-5656.

Chuah, K. (2014). Morpheus UNIMAS: Strengthening Student Engagement in Blended Learning Environments. 10.13140/2.1.4195.9207.

Contreras, J. \& Hilles, S. M. (2014). Assessment in E-Learning Environment Readiness of Teaching Staff, Administrators, and Students of Faculty of Nursing-Benghazi University.

Dent, C. (2019, April 14). Moodle's Founder and CEO, Martin Dougiamas, receives an Honorary Doctorate from Université catholique de Louvain. Retrieved from https://moodle.com/news/moodles-founder-ceo-martin-dougiamas-receiveshonorary-doctorate-universite-catholique-de-louvain/.

Dublin, L. \& Cross, J. (2002). Implementing eLearning: Getting the Most from Your eLearning Investment. ASTD International.

ELearning

Advisor. (n.d.).

Retrieved

from

https://www.swinburneonline.edu.au/careers/latest-roleopportunities/elearning-advisor. 
Folorunso, O., Ogunseye, O. S., \& Sharma, S. K. (2006). An exploratory study of the critical factors affecting the acceptability of e-learning in Nigerian universities. Information Management and Computer Security, 14(5), 496-505.

Gogos, R. (2016, May 06). A brief history of elearning (infographic). Retrieved from https://www.efrontlearning.com/blog/2013/08/a-brief-history-of-elearninginfographic.html.

Henry, P. (2001). E-learning technology, content and services. "E-learning technology, content and services", Education + Training, 9.

Hindi, N., \& Miller, D. \& Wenger, J. (2004). Computer Literacy: Implications for Teaching a College-Level Course. Journal of Information Systems Education. 13.

Hofmann, D. W. (2002). Internet-Based Distance Learning in Higher Education. Tech Directions, 62, 28-32.

Hong, K. S., Lai, K. W., \& Holton, D. (2003). Students' satisfaction and perceived learning with a Webbased course. Journal of Educational Technology \& Society 6(1). Retrieved January 15, 2004, from http://ifets.ieee.org/periodical/vol 1 2003/v 1 2003.html.

Horton, W. (2011). e-Learning by Design, Wiley.

eLearning Engagement: A Formula for Success. (2020). Retrieved 16 August 2020, from https://www.learnupon.com/blog/elearning-engagement/.

Hu, M. \& Li, H. (2017). Student Engagement in Online Learning: A Review. International Symposium on Educational Technology. 39-43. 10.1109/ISET.2017.17.

Kumar, S. (2015, July 08). 5 Common Problems Faced by Students In eLearning And How To Overcome Them. Retrieved from https://elearningindustry.com/5-commonproblems-faced-by-students-in-elearning-overcome.

Leidner, D. E., \& Jarvenpaa, S. L. (1993). The information age confronts education: Case studies on electronic classrooms. Information Systems Research, 4(1), 24-54.

Mahmood, M. A., Hall, 1. \& Swanberg, D. L. (2001). Factors affecting information technology usage: A meta-analysis of the empirical literature. Journal of Organizational Computing and Electronic Commerce, 11, 107-130.

Moodle - Open-source learning platform. (n.d). Retrieved from https://moodle.org/.

Owston, R. D., Sinclair, M. \& Wideman, H. (2008). Blended Learning for Professional Development: An Evaluation of a Program for Middle School Mathematics and Science Teachers. Teachers College, Columbia University, Vol 110 No 5.

Pongpech, J. (2013). E-learning as a supportive learning tool for a traditional class. KKU Engineering Journal, 32, 727-732.

Reffat, R. (2003). Developing a successful e-government. In: Symposium on eGovernment: Opportunities and Challenge. Muscat Municipality, Oman, 2003.

Sanders Lopez, E., \& Nagelhout, E. (1995). Building a model for distance collaboration in the computer assisted business communication classroom. Business Communication Quarterly, 58(2), 15-22.

Steeg, T. (2005). E-learning as technology, e-learning as learning. IDATER on-line conference. Loughborough: Loughborough University. 
Tarkzadeh, G., \& Koufteros, X. (1994). Factorial validation of a computer self-efficacy scale and the impact of computer training. Educational and Psychological Measurement, 54(3), 813- 821.

UNIMAS MOOC - UNIMAS MOOC. (n.d.). Retrieved from https://www.openlearning.com/unimasmooc.

Wan, C. D. (2007). Public and Private Higher Education Institutions in Malaysia: Competing, Complementary or Crossbreeds as Education Providers. [PDF file].

Webster, J., \& Hackley, P. (1997). Teaching effectiveness in technology-mediated distance learning. Academy of Management Journal, 40(6), 282-309.

Young, B. (2018, April 30). Top 3 Advantages of Moodle. Retrieved from https://elearningindustry.com/advantages-of-moodle-top-3.

Zare, M., Sarikhani, R., Salari, M. \& Mansouri, V. (2016). The Impact of E-learning on University Students' Academic Achievement and Creativity. Journal of Technical Education and Training. 8. 25-33

Zhu, C. \& Valcke, M. (2010). Chinese Students' perceptions of a collaborative e-learning environment and factors affecting their performance: implementing a Flemish elearning course in a Chinese educational context. Asia Pacific Education Review. 10. $225-235$. 
Creative Commons licensing terms

Authors will retain the copyright of their published articles agreeing that a Creative Commons Attribution 4.0 International License (CC BY 4.0) terms will be applied to their work. Under the terms of this license, no permission is required from the author(s) or publisher for members of the community to copy, distribute, transmit or adapt the article content, providing a proper, prominent and unambiguous attribution to the authors in a manner that makes clear that the materials are being reused under permission of a Creative Commons License. Views, opinions and conclusions expressed in this research article are views, opinions and conclusions of the author(s). Open Access Publishing Group and European Journal of Open Education andE-learning Studies shall not be responsible or answerable for any loss, damage or liability caused in relation to/arising out of conflict of interests, copyright violations and inappropriate or inaccurate use of any kind content related or integrated on the research work. All the published works are meeting the Open Access Publishing requirements and can be freely accessed, shared, modified, distributed and used in educational, commercial and non-commercial purposes under a Creative Commons Attribution 4.0 International License (CC BY 4.0). 